\title{
A particle agglutination assay for rapid identification of heparin binding to coagulase- negative staphylococci
}

\author{
CORINA PASCU, SIIRI HIRMO, A. LJUNGH and T. WADSTRÖM \\ Department of Medical Microbiology, University of Lund, Sölvegatan 23, S-223 62 Lund, Sweden
}

\begin{abstract}
The heparin-binding properties of six different species of coagulase-negative staphylococci were examined by a particle agglutination assay. Heparin (mol.wt 4000-6000), mildly treated with sodium periodate, was covalently coupled to amino-modified latex beads $(0.72 \mu \mathrm{m}$ diameter). The particle agglutination assay was validated by comparing results with the adhesion (percentage binding of adherent cells) of coagulase-negative staphylococcal strains to heparinised microtitration plates. Of 38 different coagulasenegative staphylococcal strains tested, 30 showed agglutination reactivity with heparincoated latex beads. Strains of different coagulase-negative staphylococcal species agglutinated heparin-coated latex beads to various extents (e.g., cells of Staphylococcus haemolyticus strains reacted more strongly than cells of $S$. epidermidis strains). The agglutination reaction was significantly inhibited by fucoidan, suramin, $\lambda$-carrageenan and other sulphated compounds, but not by non-sulphated carbohydrate polymers such as hyaluronic acid. Agglutination of staphylococcal cells with heparin-coated latex beads was completely blocked by a cell-surface extract. These results suggest that structures responsible for heparin binding are exposed on the cell surface.
\end{abstract}

\section{Introduction}

Heparan sulphate glycosaminoglycans (GAGs) form a complex heterogeneous family of macromolecules composed of linear sulphated polysaccharide chains, which are associated with epithelial and mesenchymal cell surfaces and extracellular matrix proteins (ECM) [1].

A number of biological effects have been attributed to heparin since its discovery almost 80 years ago. Many of these are independent of its anticoagulant activity. Heparin and heparan sulphate are believed to possess various biological activities that include the ability to modulate tissue homeostasis, wound healing, cell differentiation, cell proliferation and inflammation [2].

Several studies have shown that heparin and other GAGs are involved in the adherence to eukaryotic cells of pathogenic microbes such as herpes simplex, Chlamydia trachomatis, Bordetella pertussis, Streptococcus mutans, Trypanosoma cruzi, Helicobacter pylori and Leishmania donovani [3-10].

A previous study showed that Staphylococcus aureus and coagulase-negative staphylococci (CNS) interact

Received 9 Nov. 1995; revised version accepted 26 Feb. 1996.

Corresponding author: Professor T. Wadström. with heparan sulphate $[11,12]$ and other ECM molecules, i.e., fibronectin, vitronectin, thrombospondin and lactoferrin. All these proteins contain heparinbinding domains $[13,14]$. CNS comprise $>25$ different species of staphylococci that belong to the skin commensals of man and animals. A few of these species can infect intravascular catheters and prosthetic devices, and one of them, $S$. epidermidis, is the dominant cause of infections associated with biomaterials [15-17].

Among new approaches to prevent the microbial colonisation of intravascular catheters, some reports have dealt with heparin and heparin-like substances coated on catheters $[12,15]$. Heparinised devices are used clinically because of their thrombo-resistant properties. The risk of bacteraemia with heparinised catheters was reduced to half for many pathogens, but CNS were still the most frequent micro-organisms to be isolated in both bacteraemia and colonisation of heparinised catheters $[12,15]$.

\section{Materials and methods}

\section{Chemicals}

Heparin (mol. wt 4000-6000) was purchased from Fluka (Heidelberg, Germany). Amino-modified latex beads (AML, bead diameter $0.72 \mu \mathrm{m}$ ) were purchased from Seradyn Inc. Particle Technol Division (Indianapolis, 
IN, USA) and latex beads (control L-05031-02, bead diameter $0.8 \mu \mathrm{m}$ ), were from Difco. Azure A, bovine serum albumin, dextran sulphate (mol.wt 8000), fucoidan, $\lambda$-carrageenan from Gigantia aciculaire and G. pistillata, colominic acid, Evans blue, hyaluronic acid from bovine trachea, pentosan polysulphate, sodium acetate, sodium periodate, pepsin, pronase E, proteinase $\mathrm{K}$, trypsin, Trypan blue and tunicamycin (T-7765) from Streptomyces species were obtained from Sigma. Fragmin ${ }^{\circledR}$ (low molecular heparin; mol.wt 5000) and merthiolate were purchased from Kabi AB, Stockholm, Sweden). Suramin, commercially available as Germanin $^{\circledR}$, was from Bayer AG (Leverkusen, Germany) and Tween 20 from Merck AG (Darmstadt, Germany). Blood agar (BA) base was purchased from Lab M (Salford), and supplemented with horse blood 4\%. Brain Heart Infusion (BHI), Tryptic Soy (TS) and Todd-Hewitt (TH) broths were from Difco. All buffers and chemicals were of analytical grade.

\section{Bacterial strains and growth conditions}

S. aureus strains Cowan 1 and ISP 546, strains of six different CNS species isolated from patients with osteomyelitis and biomaterial-associated infections, and Micrococcus spp. isolated from blood cultures were studied. The strains were cultured on BA and in $\mathrm{TH}, \mathrm{BHI}$ and $\mathrm{TS}$ broth at $37^{\circ} \mathrm{C}$ for $24 \mathrm{~h}$ on an orbital shaker. Bacterial cells were harvested in the late stationary phase by centrifugation $(3000 \mathrm{rpm}$ for $20 \mathrm{~min}$ ), washed twice with $0.07 \mathrm{M}$ phosphate-buffered

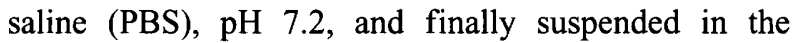
same buffer at a final concentration of $10^{9} \mathrm{cfu} / \mathrm{ml}$, and used promptly in the particle agglutination assay (PAA). Helicobacter pylori strain 25 was included as a positive control [8,9].

\section{Cell surface extract}

For cell surface extraction, cells of a strain of $S$. haemolyticus, SM 131, were washed twice, resuspended in $2.5 \mathrm{ml}$ of $1.0 \mathrm{M} \mathrm{LiCl}, \mathrm{pH} 5.0$, and incubated for $2 \mathrm{~h}$ at $45^{\circ} \mathrm{C}$ with agitation. After centrifugation (3000 $\mathrm{g}, 30 \mathrm{~min}$ ) supernate was dialysed overnight at $4^{\circ} \mathrm{C}$ against PBS. The protein content was determined by a BioRad microassay (BioRad, Richmond, CA, USA). The extract was stored at $-20^{\circ} \mathrm{C}$.

\section{Tunicamycin treatment of staphylococci}

S. epidermidis H9-E and S. haemolyticus SM131 and E 2498 cells were grown at $37^{\circ} \mathrm{C}$ for $24 \mathrm{~h}$ with continuous shaking in $\mathrm{TH}$ broth supplemented with tunicamycin $12.5 \mu \mathrm{g} / \mathrm{ml}$ [18]. The cells were washed, suspended in PBS and tested in the PAA as described below.

\section{Preparation of latex reagents}

Heparin PAA reagents were prepared by both covalent coupling and electrostatic adsorption to latex beads.
Covalent coupling. Heparin was bound covalently to AML beads after mild periodate oxidation [19]. Heparin dissolved in $0.1 \mathrm{M}$ sodium acetate buffer (NaAc, pH 5.5) at a concentration of $2 \mathrm{mg} / \mathrm{ml}$ was treated with $100 \mu \mathrm{l}$ of $0.1 \mathrm{M} \mathrm{NaIO}_{4}$, which was added in $20-\mu 1$ volumes over $10 \mathrm{~min}$. The reaction mixture was incubated for a further $20 \mathrm{~min}$ in the dark and oxidised heparin was separated from $\mathrm{NaIO}_{4}$ by gel filtration with a Sephadex G-25 column equilibrated with $0.1 \mathrm{M} \mathrm{NaAc}$ buffer ( $\mathrm{pH} 5.5$ ). One hundred $\mu 1$ of AML particles (Seradyn, IN, USA; solids 10\%, diameter $=0.722 \mu \mathrm{m}$ ) were incubated with $1 \mathrm{ml}$ of oxidised heparin solution overnight at room temperature. Finally, the heparin-coated AML particles were washed twice in PBS and resuspended in the same buffer at a final concentration of $1 \%$ total solids and stored at $4^{\circ} \mathrm{C}$ until used.

Adsorption. Heparin was electrostatically adsorbed to the latex beads (Difco; diameter $=0.81 \mu \mathrm{m}$ ). Briefly, a $1.0-\mathrm{ml}$ sample of latex particle suspensions was mixed with $3.0 \mathrm{ml}$ of $0.17 \mathrm{M}$ glycine- $\mathrm{NaOH}$ buffer ( $\mathrm{pH} 8.2$ ). Heparin $(500 \mu \mathrm{g})$ was added and the mixture was kept at $30^{\circ} \mathrm{C}$ overnight on a horizontal shaker at $50 \mathrm{rpm}$. The mixture was centrifuged $\left(9200 \mathrm{~g}, 15 \mathrm{~min}, 10^{\circ} \mathrm{C}\right)$, and the pellet was suspended in $2 \mathrm{ml}$ of $0.17 \mathrm{M}$ glycine$\mathrm{NaOH}$ buffer containing BSA $0.05 \%$ and merthiolate $0.01 \%$ and kept at $4^{\circ} \mathrm{C}$ for $12 \mathrm{~h}$.

The presence of heparin on the latex particles was detected by a chromatic method with Azure A stain [20]. Control latex beads were prepared with BSA $0.05 \%$ in the same manner as the heparin.

\section{Particle agglutination assay (PAA)}

Latex reagent $(10 \mu \mathrm{l})$ was placed on glass slides, and an equal volume of a bacterial cell suspension $\left(10^{9} \mathrm{cfu} /\right.$ $\mathrm{ml}$ ) was added. The two drops were mixed gently, and the agglutination reaction was read after 2 min [21]. Each strain was tested in duplicate and assays were repeated on two different days with separately prepared bacterial suspensions. Strains were tested for autoaggregation by mixing one drop of a bacterial suspension with one drop of PBS on a glass slide.

\section{Particle agglutination inhibition assay}

The bacterial suspension $\left(10^{8}\right.$ cells in $\left.100 \mu \mathrm{l}\right)$ was preincubated for $1 \mathrm{~h}$ at $20^{\circ} \mathrm{C}$ with $100 \mu \mathrm{l}$ of inhibitor at a final concentration of $1 \mathrm{mg} / \mathrm{ml}$ and then mixed with PAA reagents. PBS was used as a control.

In another series of experiments, $100 \mu \mathrm{l}$ of bacterial cell-surface extract (protein concentration $400 \mu \mathrm{g} / \mathrm{ml}$ ) was incubated with an equal volume of coated latex beads for $30 \mathrm{~min}$ at $20^{\circ} \mathrm{C}$. After that, $10 \mu \mathrm{l}$ of bacterial cell suspension were mixed with $10 \mu \mathrm{l}$ of mixture (cell surface extract + heparin-coated latex beads) and 
checked for agglutination abilities. Agglutination was recorded after $2 \mathrm{~min}$ and scored as described above.

\section{Heat and enzyme treatment}

Washed cells of $S$. haemolyticus strains SM 131 and E 2498 were heated at $90^{\circ} \mathrm{C}$ for $30 \mathrm{~min}$, cooled rapidly, and then used in the PAA. Bacterial cells were also treated with different enzymes (Table 3 ) at $37^{\circ} \mathrm{C}$ for $1 \mathrm{~h}$. The cells were washed carefully twice with PBS to remove enzyme residues, resuspended in the same buffer to $10^{9} \mathrm{cfu} / \mathrm{ml}$ and tested in the PAA. The incubation conditions for each enzyme were according to the Worthington Enzyme Manual (Worthington Biochemical Corp., Freehold, NJ, USA); the ratio of enzyme to substrate was $100 \mu \mathrm{g} / 100 \mu \mathrm{l}$.

\section{Periodate treatment}

The bacterial cell suspensions $\left(500 \mu \mathrm{l}, 10^{9} \mathrm{cfu} / \mathrm{ml}\right)$ were pre-incubated overnight with an equal volume of $100 \mathrm{mM}$ sodium periodate, at $4^{\circ} \mathrm{C}$ in the dark. After washing three times with PBS, bacterial cells were incubated further with $100 \mathrm{mM} \mathrm{NaBH} 4$ for $1 \mathrm{~h}$ at $4^{\circ} \mathrm{C}$, washed twice in PBS and finally resuspended in PBS at the original concentration [22].

\section{Adherence assay}

Bacterial adherence was quantified by a bioluminescence assay [15]. Heparin binding of staphylococcal cells was tested on microtitration plates (96 wells; Costar, Cambridge, MA, USA) with end-point-attached heparin $\left(4 \mu \mathrm{g} / \mathrm{cm}^{2}\right)$ [23]. One hundred $\mu \mathrm{l}\left(5 \times 10^{8} \mathrm{cfu} /\right.$ $\mathrm{ml})$ of bacteria were incubated on the heparin-coated surface for $1 \mathrm{~h}$ at $20^{\circ} \mathrm{C}$. The wells were washed three times with PBS-Tween $200.05 \%$ and the number of adherent bacteria was quantified by measuring the ATP content of the bound cells, as previously described [15]. Briefly, ATP was extracted from adherent bacteria in $100 \mu 1$ of trichloroacetic acid (TCA) $2.5 \%, 50 \mu 1$ of the extraction fluid was transferred to $200 \mu \mathrm{l}$ ATP Monitoring Reagent (AMR) with $750 \mu \mathrm{l} 0.1 \mathrm{M}$ Trisacetate, 2 mM EDTA, pH 7.75 (TAE) and vortex mixed for 1 min. A blank containing $200 \mu \mathrm{l}$ of AMR, $750 \mu \mathrm{l}$ of TAE and $50 \mu \mathrm{l}$ of TCA $2.5 \%$ was prepared simultaneously. The amount of ATP was recorded in a luminometer (LKB Wallac 1250 Luminometer, Turku, Finland). Results (percentage binding) were expressed as the mean value of triplicate samples.

\section{Results}

Evaluation of the agglutination assaysagglutination strength

The agglutination scored in the PAA showed different intensities with cells of different staphylococcal strains. According to this and for the purpose of semiquantitative analysis, the agglutination was classified in four numerically assigned categories: no macroscopically visible agglutination $(0=-)$, weak $(1=+)$, moderate $(2=++)$, and strong $(3=+++)$ agglutination $[14,21]$.

\section{$P A A$ reactivity of $C N S$ strains with heparin-coated latex beads}

Of a total of 38 strains from six different CNS species tested, 30 agglutinated with heparin-coated latex beads. However, there was great strain variability, and different CNS species agglutinated heparin-coated latex beads to varying extents (e.g., cells of S. haemolyticus reacted more strongly than cells of $S$. epidermidis strains) (Fig. 1).

\section{Influence of culture media}

Reference type culture collection strains $S$. aureus Cowan1, S. haemolyticus SM31 and E 2498, $S$. epidermidis H9-E, 3380 and RP 12 and S. saprophyticus TW 111 were grown on BA, in BHI, TH broth and TS broth and tested for PAA reactivity with heparin-coated latex beads. TH broth and BA were optimal for CNS strains because only a few strains autoaggregated. Heparin binding to staphylococcal cells, harvested in the late stationary phase, was influenced by the culture medium and growth conditions. TH broth enhanced the expression of heparinbinding surface components (stronger agglutination reaction) of $S$. aureus and CNS strains compared to cells of the same strains grown on BA (Table 1).

\section{Inhibition of PAA}

Pre-incubation of $S$. haemolyticus SM131 cells with various glycosaminoglycans and polysulphated com-

Table 1. Effect of culture media on agglutination patterns of some $S$. aureus and CNS cells with heparin-coated beads

\begin{tabular}{lcccc}
\hline & \multicolumn{4}{c}{ PAA score* in } \\
\cline { 2 - 5 } Strain & TH & BA & BHI & TS \\
\hline $\begin{array}{l}\text { S. aureus } \\
\text { Cowan 1 }\end{array}$ & 3 & 2 & 3 & 0 \\
& & & & \\
S. haemolyticus & 3 & 3 & AA & $1-2$ \\
SM 131 & 2 & 2 & 2 & 2 \\
E 2498 & & & & \\
S. epidermidis & 2 & 1 & 1 & NT \\
3380 & 3 & 2 & NT & 1 \\
H9-E & AA & 2 & AA & 1 \\
RP 12 & & & & \\
S. saprophyticus & 2 & 0 & 2 & 0 \\
TW 111 & 2 & 0 & 2 & \\
\hline AA, aut & & & & \\
\end{tabular}

AA, autoaggregating; NT, not tested; BA, blood agar; TH, ToddHewitt broth; BHI, brain heart infusion broth; TS, tryptic soy broth. * PAA reactions were scored from strongly positive 3 or 2 to weakly positive 1 , or negative 0 . 


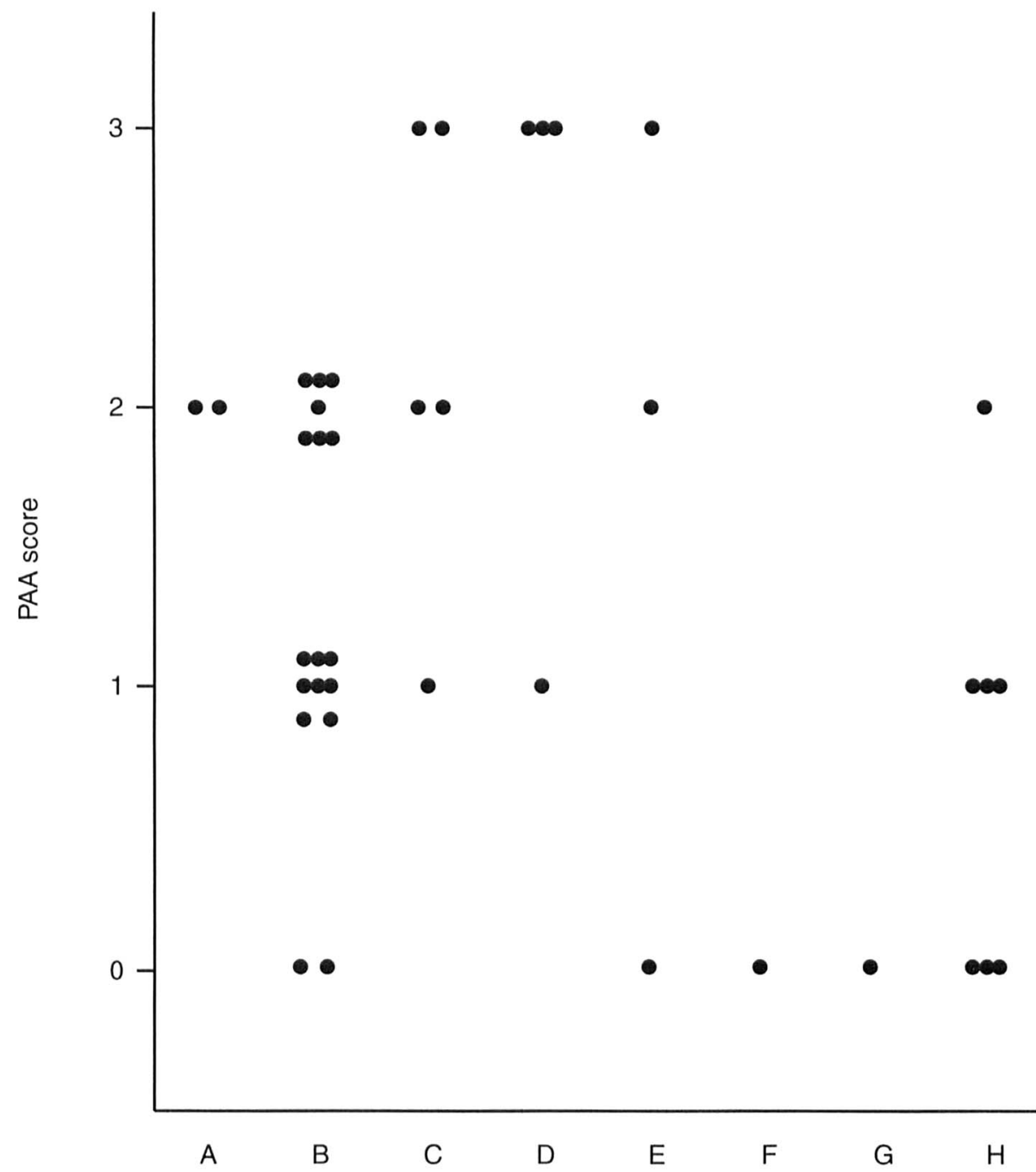

Fig. 1. Agglutination patterns of staphylococcal cells with heparin-coated latex beads. A, $S$. aureus (2 strains); B, $S$. epidermidis (17); C, S. haemolyticus (5); D, S. hominis (4); E, S. capitis (3); F, S. saprophyticus (1); G, Micrococcus luteus (1); $\mathbf{H}$, other CNS strains (7). Each dot represents one bacterial strain. Experimental procedures are described in Materials and methods.

pounds blocked the PAA reactivity with heparin-coated latex beads to different extents. Fragmin ${ }^{\circledR}$, fucoidan, suramin, $\lambda$-carrageenan, Trypan blue and Evans blue (at final concentrations of $1 \mathrm{mg} / \mathrm{ml}$ ) almost abolished the agglutination of $S$. haemolyticus SM131 and E 2498 cells. Heparin blocked the agglutination to a lesser extent and hyaluronic and colominic acid did not affect the agglutination ability of $S$. haemolyticus SM131 cells with heparin-coated beads (Table 2).

The cell surface extract of $S$. haemolyticus SM131 cells completely inhibited the agglutination of heparincoated latex beads (Table 2).

\section{Protease and heat treatment}

Cells of S. haemolyticus strains SM131 and E 2498 were sensitive to protease treatment (Table 3). Cellsurface structures of $S$. haemolyticus E 2498 were sensitive to all proteases used, whereas those of $S$.
Table 2. Influence of potential inhibitors on the agglutination of $S$. haemolyticus SM131 and E 2498 cells with heparin-coated latex beads

\begin{tabular}{lcc}
\hline & \multicolumn{2}{c}{ PAA score* with strain } \\
\cline { 2 - 3 } Inhibitor & SM 131 & E 2498 \\
\hline (1 mg/ml final concentration) & 3 & 2 \\
\hline PBS (control) & 0 & 0 \\
Cell-surface extract & 1 & 1 \\
Heparins and heparin-like molecules & 2 & 1 \\
$\quad$ Fragmin ${ }^{\circledR}$ (mol. wt 5000) & 1 & 1 \\
$\quad$ Heparin (mol. wt 4000-6000) & 1 & 1 \\
Suramin & 1 & 1 \\
Fucoidan & 1 & 1 \\
$\quad \lambda$-Carrageenan & & \\
$\quad$ Pentosan polysulphated & 1 & 1 \\
Sulphated dyes & 1 & 1 \\
$\quad$ Evans blue & 1 & 1 \\
$\quad$ Trypan blue & & \\
$\quad$ Congo Red & 3 & 2 \\
Non-sulphated polymers & 3 & 2 \\
$\quad$ Hyaluronic acid $\dagger$ & 3 & \\
Colominic acid &
\end{tabular}

${ }^{*}$ See footnote to Table 1

$\dagger \alpha-2-8-$ Polysialic acid. 
haemolyticus SM131 were more protease-resistant (Table 3 ). Only pronase $\mathrm{E}$ and proteinase $\mathrm{K}$ treatment of cells of $S$. haemolyticus SM 131 abolished the agglutination reaction with heparin-coated latex beads. Heat treatment $\left(90^{\circ} \mathrm{C}, 30 \mathrm{~min}\right)$ of cells of both $S$. haemolyticus SM 131 and E 2498 decreased agglutination intensity with heparin-coated latex beads (Table 3 ).

\section{Tunicamycin treatment of staphylococci}

Although tunicamycin, an antibiotic that was found to block the protein glycosylation of bacterial surfaces [18], at $12.5 \mu \mathrm{g} / \mathrm{ml}$ subinhibitory concentration, affects the growth of $S$. haemolyticus SM 131 and E 2498 and $S$. epidermidis H9-E, the agglutination reaction was partially abolished for cells of S. haemolyticus SM 131 and $S$. epidermidis $\mathrm{H} 9-\mathrm{E}$, whereas no effect was observed in the agglutination by $S$. haemolyticus $\mathrm{E}$ 2498 cells, compared with heparin agglutination caused by non-antibiotic-treated bacterial cells (Table 4).

\section{Periodate treatment}

Further experiments were made to study the importance of carbohydrates in the binding of heparin to staphylococcal cells. The heparin agglutination was abolished by periodate treatment of cells of $S$. haemolyticus SM 131 and E 2498 (Table 3).

\section{Bioluminescence assay}

Agglutination results (PAA score) were compared with the heparin binding results of staphylococcal cells

Table 3. PAA reactivity of $S$. haemolyticus SM131 and E 2498 cells with heparin-coated latex beads after heat, enzymic and periodate treatments

\begin{tabular}{lcc}
\hline & \multicolumn{2}{c}{ PAA score* with S. haemolyticus } \\
\cline { 2 - 3 } Treatment & SM 131 & E 2498 \\
\hline Buffer (PBS, pH 7.2) & 3 & 2 \\
Pronase E & 0 & 0 \\
Trypsin & 2 & 0 \\
Proteinase K & 1 & 0 \\
Pepsin & 1 & 0 \\
Heat treatment & & \\
(90 C 30 min) & 1 & 1 \\
Periodate treatment & 0 & 0 \\
\hline
\end{tabular}

*See footnote to Table 1 .

Table 4. Effect of a subinhibitory concentration of tunicamycin, in Todd-Hewitt broth, on the ability to agglutinate heparin-coated latex beads of $S$. haemolyticus SM 131 and E 2498 and S. epidermidis H9-E

\begin{tabular}{lccc}
\hline & \multicolumn{3}{c}{ Heparin-PAA reaction* } \\
\cline { 2 - 3 } Tunicamycin & \multicolumn{2}{c}{$S$. haemolyticus } & \\
\cline { 2 - 3 }$(\mu \mathrm{g} / \mathrm{ml})$ & S. epidermidis \\
\hline 0 (Control) & 3 & E 2498 & H9-E \\
12.5 & 2 & 2 & 3 \\
\hline
\end{tabular}

${ }^{*}$ See footnote to Table 1 .
(Fig. 2). The three reaction groups positive for heparinPAA with scores of 3,2 and 1, corresponded to median values of $7 \%, 2.6 \%$ and $1 \%$ binding to heparinised microtitration plates. No visible agglutination reaction (0) corresponded to no detectable adherence of staphylococci to the heparinised microtitration plates, indicating a high sensitivity of the PAA test described in this study (Fig. 2).

\section{Discussion}

The attachment of bacteria to host tissues is the initial event in colonisation and the development of an infection. Staphylococci become associated with host tissue components in open wounds and biomaterialassociated infections by lectin-like bacterial components (often termed 'adhesins'), with specific structures on the host cells and ECM and by hydrophobic and electrostatic interactions $[16,17,24]$.

Glycosaminoglycans such as heparin interact with and modulate the structure, function and metabolism of a wide variety of host proteins and enzymes including ECM, growth factors, pro-inflammatory chemokines and leucocyte proteases, such as cathepsin [2]. Heparin interacts with these proteins through multiple and specific electrostatic forces between the polyanionic groups of the glycosaminoglycan chain and the positively charged amino acids of those proteins [2].

Heparin-coated biomaterials have clinical application today [15-17] and it is important to study heparinCNS interactions in order to understand the behaviour of heparinised biomaterials and also to develop methods to block the CNS adhesion on these surfaces. Therefore, this study focused on this topic and developed a rapid assay (PAA) for detecting heparin binding to CNS strains. Such an assay was shown to give reliable data on the binding properties of serum and ECM proteins to staphylococci $[14,21]$ and other bacteria [25-27]. By performing the tests in duplicate and repeating them on separate days, highly reproducible results were obtained. Amino-modified latex beads from Seradyn and non-activated latex beads from Difco were the most suitable for coating with heparin. Uncoated latex particles caused non-specific agglutination because of the strong negative charge and high surface hydrophobic properties [14, 25]. Coating of the particles with ovalbumin was inadequate as a negative control as staphylococci have often been found to bind to ovalbumin (unpublished data). BSA reduced the non-specific binding of the particles and was used as a negative control. PAA reagents were stable during storage for 3 months at $4^{\circ} \mathrm{C}$. The reagents do not withstand freezing.

The fact that proteases, heat, periodate and tunicamycin treatments of staphylococcal cells decreased the 


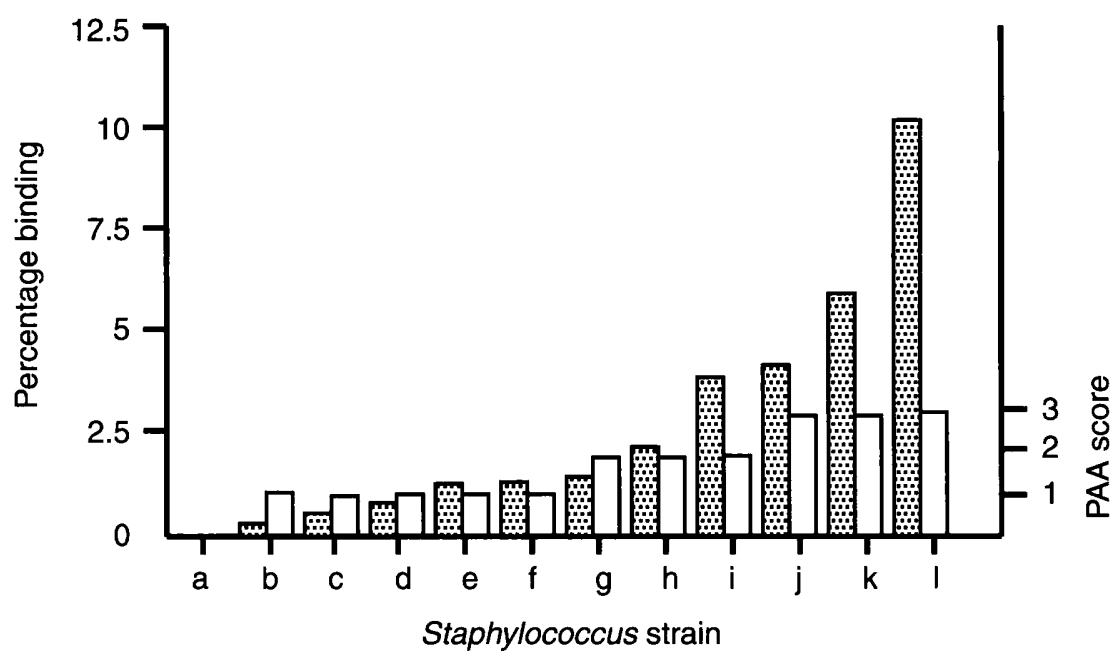

Fig. 2. Comparison between PAA score $(\square)$ and percentage heparin binding ([i:) of cells of 10 CNS strains ( $S$. epidermidis BD 7743, a; BD 1897, b; BD 16301, c; BD 6694, d; BD 13807, e; BD 9229, f; S. haemolyticus E 2498, i; MD-7, k; S. hominis BD 8127, j; BD 8008, 1) and two $S$. aureus strains (ISP 546, g; Cowan 1, h) determined by bioluminescence method on heparinised microtitration plates. Bacterial preparations and binding assays are described in Materials and methods.

heparin-PAA reactivity suggests that both protein and carbohydrate moieties are responsible for heparin binding (Tables 3,4). The agglutination of CNS with heparin was blocked by various polyanions but not by non-sulphated macromolecules, indicating the importance of the sulphation of these inhibitors. It is interesting that polysulphated oligosaccharides such as pentosan polysulphate, fucoidan and dextran sulphate were potent inhibitors (Table 2). These compounds all have O-sulphated groups and a saccharide backbone which are distinct from those of heparin and heparin sulphate. These results suggest that the agglutination of staphylococcal cells with heparin most probably involved hydrophobic surface proteins with charged sulphur-containing groups, as the binding was efficiently inhibited by polysulphated but not by non-sulphated polymers. The complete inhibition of the heparin-PAA reaction by a staphylococcal cell-surface extract indicates that the structures responsible for heparin binding are exposed on the cell surface.

This finding is particularly interesting as staphylococcal cells specifically interact with various ECM molecules, such as fibronectin, vitronectin, collagen, thrombospondin, lactoferrin and transferrin, all of which contain heparin-binding domains [13].

In conclusion, these data support the earlier observation that the attachment of CNS cells to heparinised biomaterials is mediated by surface-located proteinaceous structures $[12,15]$. Nevertheless, hydrophobic and electrostatic interactions may be important in the pathogenesis of biomaterial-associated infections caused by CNS. Further studies on the hydrophobic surface components, or hydrophobins [24] of CNS should be carried out.
This study was supported by grants from the Swedish Medical Research Council (16 X-04723), the Technical Science Research Council, the Board for Technical Development (NUTEK), the Medical Faculty of the University of Lund and the Thelma Zoégas Foundation. We also thank Professor O. Larm and I. Gouda from Medicarb AB, Bromma, Sweden for supplying the heparinised microtitration plates.

\section{References}

1. Fransson L-A. Structure and functions of cell associated proteoglycans. FEBS Lett 1987; 12: 406-411.

2. Tyrrell DJ, Kilfeather S, Page CP. Therapeutic uses of heparin beyond its traditional role as an anticoagulant. Trends Pharmacol Sci 1995; 16: 198-204.

3. Lycke E, Johansson M, Svennerholm B, Lindahl U. Binding of Herpes simplex virus to cellular heparan sulphate, an initial step in the adsorption process. J Gen Virol 1991; 72: 11311137.

4. Chen JC-R, Stephens RS. Trachoma and LGV biovars of Chlamydia trachomatis share the same glycosaminoglycandependent mechanism for infection of eukaryotic cells. Mol Microbiol 1994; 11: 501-507.

5. Menozzi FD, Gantiez C, Locht C. Interaction of the Bordetella pertussis filamentous hemagglutinin with heparin. FEMS Microbiol Lett 1991; 78: 59-64.

6. Choi SH, Stinson MW. Purification of a Streptococcus mutans protein that binds to heart tissue and glycosaminoglycans. Infect Immun 1989; 57: 3834-3840.

7. Ortega-Barria E, Pereira MEA. A novel T. cruzi heparinbinding protein promotes fibroblast adhesion and penetration of engineered bacteria and Trypanosomes into mammalian cells. Cell 1991; 67: 411-421.

8. Ascencio F, Fransson L-Å, Wadström T. Affinity of the gastric pathogen Helicobacter pylori for the N-sulphated glycosaminoglycan heparan sulphate. $J$ Med Microbiol 1993; 38: 240 244

9. Hirmo S, Utt $\mathrm{M}$, Ringer $\mathrm{M}$ et al. Inhibition of heparan sulphate and other glycosaminoglycans binding to Helicobacter pylori by various polysulphated carbohydrates. FEMS Immunol Med Microbiol 1995; 10: 301-306.

10. Butcher BA, Sklar LA, Seamer LC, Glew RH. Heparin enhances the interaction of infective Leishmania donovani promastigotes with mouse peritoneal macrophages. A fluorescence flow cytometric analysis. $J$ Immunol 1992; 148: 28792886.

11. Liang OD, Ascencio F, Fransson L-Å, Wadström T. Binding of 
heparan sulphate to Staphylococcus aureus. Infect Immun 1992; 60: 899-906.

12. Paulsson M, Gouda I, Larm O, Ljungh A. Adherence of coagulase-negative staphylococci to heparin and other glycosaminoglycans immobilized on polymer surfaces. $J$ Biomed Mater Res 1994; 28: 311-317.

13. Ljungh $\AA$, Wadström $\mathrm{T}$. Binding of extracellular matrix proteins by microbes. Methods Enzymol 1995; 253: 501-514.

14. Paulsson M, Ljungh $\AA$, Wadström T. Rapid identification of fibronectin, vitronectin, laminin, and collagen cell surface binding proteins on coagulase-negative staphylococci by particle agglutination assays. J Clin Microbiol 1992; 30: 2006-2012.

15. Appelgren P, Ransjö U, Bindslev L, Larm O. Does surface heparinisation reduce bacterial colonisation of central venous catheters? Lancet 1994; 345: 130.

16. Wadström T, Eliasson I, Holder I, Ljungh A (eds). Pathogenesis of wound and biomaterial-associated infections. London, Springer-Verlag. 1990.

17. Wadström T, Holder IA, Kronvall G. Molecular pathogenesis of surgical infections. 21st Erik K. Fernstrom Symposium. Stuttgart, Gustav Fisher Verlag. 1994.

18. Pulverer G, Beuth J, Ko HL, Solter J, Uhlembruck G. Modification of glycosylation by tunicamycin treatment inhibits lectin-mediated adhesion of Streptococcus pneumoniae to various tissues. Zentralbl Bakteriol Mikrobiol Hyg A 1987; 266: 137-144.

19. Mach H, Volkin DB, Burke CJ et al. Nature of the interaction of heparin with acidic fibroblast growth factor. Biochemistry 1993; 32: $5480-5489$.
20. Lam LH, Silbert JE, Rosenberg RD. The separation of active and inactive forms of heparin. Biochem Biophys Res Commun 1976; 69: $570-577$.

21. Naidu AS, Paulsson M, Wadström T. Particle agglutination assays for rapid detection of fibronectin, fibrinogen, and collagen receptors on Staphylococcus aureus. J Clin Microbiol 1988; 26: 1549-1554.

22. Mamo W, Fröman G. In vivo-like antigenic surface properties of Staphylococcus aureus from bovine mastitis induced upon growth in milk whey. Microbiol Immunol 1994; 38: 801-804.

23. Pejler G, Lindahl U, Larm O, Scholander E, Sandgren E, Lundblad A. Monoclonal antibodies specific for oligosaccharides prepared by partial nitrous acid deamination of heparin. $J$ Biol Chem 1988; 263: 5197-5201.

24. Ofek I, Doyle RJ. Principles of bacterial adhesion. In: Bacterial adhesion to cells and tissues. New York, Chapman and Hall. 1994; 1-15.

25. Ascencio F, Aleljung P, Wadström T. Particle agglutination assays to identify fibronectin and collagen cell surface receptors and lectins in Aeromonas and Vibrio species. Appl Environ Microbiol 1990; 56: 1926-1931.

26. Eiring P, Manncke B, Gerbracht K, Werner H. Bacteroides fragilis adheres to laminin significantly stronger than Bacteroides thetaiotaomicron and other species of the genus. Int $J$ Med Microbiol Virol Parasitol Infect Dis 1995; 282: 279-286.

27. Reza AH, Ascencio F, Ljunch Å, Wadström T. Particle agglutination assay for detection of albumin and IgG binding cell surface components of Helicobacter pylori. Int J Med Microbiol Virol Parasitol Infect Dis 1995; 282: 255-264. 